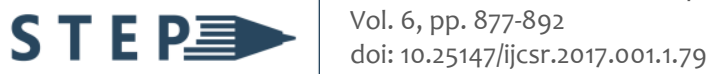 \\ https://stepacademic.net
}

\section{Short Paper \\ Challenges of Information Technology Education Student's Online Classes during the Covid-19 Pandemic in Selected Public Colleges and Universities in the Philippines}

\author{
Francis F. Balahadia \\ College of Computer Studies \\ Laguna State Polytechnic University \\ Siniloan, Laguna, Philippines \\ francis.balahadia@lspu.edu.ph
}

Date received: August 13, 2021

Date received in revised form: November 4, 2021

Date accepted: November 22, 2021

Recommended citation:

Balahadia, F. F. (2022). Challenges of Information Technology Education Student's Online Classes during the Covid 19 in Selected Public Colleges and Universities in the Philippines. International Journal of Computing Sciences Research, 6, 877-892. doi: 10.25147/ijcsr.2017.001.1.79

\begin{abstract}
Purpose- Many educational systems across the world have shifted to online learning methodology as a measure against Covid-19 Pandemic to continue educating students. This phenomenon is causing a lot of complications to the educational system around the world in the context of developing countries, especially to the public state colleges and universities. This paper aims to identify and describe the challenges of online learning from the perspective of Information Technology Education (ITE) students in the public state colleges and universities during the COVID-19 pandemic.

Method- It used descriptive research for the conducted of the study wherein survey questionnaires were sent out via electronic survey in different state colleges and universities in the Philippines. The evaluations were calculated using descriptive statistics and Chi-square and responses were compared between their profiles using a nonparametric test.

Results- The findings obtained the demographic profile of the ITE students with the degree of BS Information Technology, BS Computer Science, and BS Information System such courses, year level, and place they live. Additionally, the study gained a significant


relationship between student profile in the device used in class, internet connectivity, student type of data connection, capability to attend online class, and their commitment to participate and submit class requirements. The study identifies different interrelated challenges such as the majority of the student only using smartphones in online learning and poor internet connection as they tried to adapt to online learning because they are committed to participating and submitting requirements.

Conclusion- The study gives insights into the current condition experienced by the students in the school administrations and officials, and faculty as well to strengthen the appropriate online teaching mode and other practices applicable to the students. It can also use to emphasize to be more responsive to the learning needs of the IT students, especially beyond the conventional classrooms.

Recommendations- It is suggested that educational institutions must create appropriate and effective content, and provide digital literacy training to current faculty to improve learning outcomes. Lastly, a strong Information Communication Technology Office that focuses on the development of a different website and mobile application that assist the need of the students and faculty may be established.

Keywords: ITE, Covid-19, challenges, online classes, public colleges and universities, Philippines

\section{INTRODUCTION}

In December 2019, COVID-19 was detected which later developed into a pandemic as it made an extensive change that affected not only Wuhan China but all other countries around the globe (Gondauri, Mikautadze, \& Batiashli, 2020). As a result, worldwide community quarantine and school closure follow to avoid the risk of virus transmission. UNESCO (2020) reported that 1,576,021, 818 learners out of $91.3 \%$ of total enrolled students in 183 countries have been affected by the virus outbreak as of April 06, 2020 (Toquero, 2020). This leads to a pandemic that most of the leaders of different countries impose restrictions and the movement of the community cause the people to experience lockdown and unemployment.

There is a variety of implementation of quarantine and the majority of the provinces in the Philippines were placed under Enhance Community Quarantine (ECQ) this include social distancing, banning of public event, mass gathering, business and school closure as declared and imposed by President Duterte (Simbulan, 2020). According to UNESCO in one of their reports, there were about 1.2 billion learners worldwide and about 28 million in the Philippines alone instructed to go home and around March 2020 as there was a steady rise in the total number of cases, especially those that included death statistics (DOH, 2020). The multidimensional implications of the pandemic were not just 
but especially involved educational, social, and economic aspects of every person either positive or negative to the dreaded virus (Radwan \& Radwan, 2020; Usak et al, 2020).

In school closure, both private and public in all levels had also had to adjust to a new situation where face-to-face interaction and mass gatherings are not allowed. Teachers and administrators were put to the task of revising and adapting course syllabi and requirements. Several teachers are experimenting with new actives such as recording and uploading their lessons for students to utilize in online learning and some were even more innovative (Fox, 2007) and used Google Classrooms, WebQuest, and other online sites, but a vast majority of teachers are unprepared to deal with online education (Toquero, 2020). Teachers and students had limited access to computers or unreliable internet access, Teachers and students used smartphones to exchange messages, notes, and materials, through text messaging, e-mail, Facebook Messenger, and Twitter (Simbulan, 2020).

Higher education took a different thrust in the hope of continuing on the academic development of the future (undergraduate and post-graduate level students) effectively discontinuing the more traditional face-to-face teaching-learning approach and shifting to online educational system alternatives (Setiawan 2020; Blankenberger \& Williams, 2020). Naciri et al (2020) study mentioned the mobile learning alternative emphasized to be an unavoidable alternative that allowed learning anytime, anyplace, and anywhere. The curriculum must be changed. Strategies must be changed as well. Higher Education Academy (2018) in their presented study towards this specific flexible learning approach, virtual learning, and online class activities will require the necessary digital literacies and the ability to work independently and autonomously while complying with the different academic requirements demandable from them.

In some instances, online classes became a concern to the status of students who are affected by this new learning method. One study observed in a private higher education institution that students did not attend the online lectures due to no or poor internet access and no computer/laptop damage (Yusuf \& Ahmad, 2020). The effects of the pandemic and other scenarios in 2020 may have significant impacts on college students, especially in public colleges and universities. which most of the students cannot afford to have good and stable internet connectivity like in the study done in Local Universities and Colleges (Abisado, et al., 2020). There has been very little research done from the public state colleges and universities but there have been done about COVID-19 from the medical field and other fields related to health sciences (Meng, Hua, \& Bian, 2020; Gondauri, Mikautadze, \& Batiashvili, 2020. As well as there is inadequate research on the field of education (Sintema, 2020; Yan, 2020) showing the challenges of students in this pandemic. However, in the field of Information technology or computing field Bringula, Batalla, and Borebor (2021) found that the student online learning experiences are difficult while Fabito et al. (2021) presented the issues of students during online learning in private universities. In other words, the prior study did not consider the challenges of ITE students, especially in the public state colleges and universities. 
On a global scale, UNICEF (2020) reported that an estimated more than 1.5 billion students of all ages are affected because of school and university closures. Shutdowns have disproportionately affected the youth. To encourage the retention of the students, the school administrations and officials must address the concerns and issues of the students in the online learning, which is the "New Normal", Information technology education or computing students had to cease all face-to-face learning activities halfway through the second semester. Student from the Information Technology Education (ITE) department is expected to adopt online learning but lack of studies dealing with assessing the different challenges of computing students especially in the public colleges and universities which there are limited educational resources found in the study of Lausa, Bringula, Bangit, and Santiago (2021). As suggested by the study of Mailizer et al. (2020) that students' voices are important and it should investigate their opinions regarding online learning to examine the challenges faced by students.

In this paper, we aimed to identify and describe the challenges to online learning from the perspective of ITE students from the public state colleges and universities during the COVID-19 pandemic. Specifically, this paper seeks to answer the following:

1. To determine the demographic profile of the computing students in online learning of selected public colleges and Universities in terms of courses, year level, learning modality, and location.

2. To determine the mode of teaching, devise use in participating class, student data connection of the respondents in online learning.

3. To determine the significant relationship among the profile of respondents to a mode of teaching, devise use in participating class, and student data connection.

4. To determine the capability to attend online classes and

a) commitment to participating classes, and

b) submitting requirements of the respondents in online learning

5. To determine the significant relationship among the capability to attend online classes and commitment to participating classes, and submitting requirements of the respondents.

The researcher would like to test the following null hypotheses:

Ho: There is no significant relationship among the profile of respondents to a mode of teaching, devise use in participating class, and student data connection.

H1: There is no significant relationship among the capability to attend online classes, commitment to participating classes, and submitting requirements of the respondents. 


\section{METHODOLOGY}

This study was conducted during the spread of the COVID-19 Pandemic in the Philippines which the majority of the big provinces were under Enhanced Community Quarantine (ECQ) and some areas are under the Moderated Enhanced Community Quarantine (MECQ) which started on September 15, 2020, until October 30, 2020. All classes in different provinces and towns were suspended because of the non-stop spreading of Covid cases around the Philippines. With these concerns, all Higher Education Institutions both Private and Public schools, colleges, and universities shifted their teaching modalities into online learning classes which lead to different challenges in coping with the accessibility to the internet, learning resources, and different restrictions in classroom settings.

This study was participated by seven (7) public colleges and universities in different provinces in the Philippines including Batangas, Laguna, Bulacan, Mindoro, Isabela, Bukidnon, and Pampanga. The HEl's were selected through convenience sampling. The universities in these provinces are the only available and willing to participate in the conduct of the study with the assistance and help of faculty members from the ITE department. A total of 1300 respondents students taking the courses of BS Information Technology, BS Computer Science, BS Information System from 1st year to 4th-year level. The said respondents had the chance of experiencing the online classes and activities.

The respondents were also coming through convenience sampling where they answer the distributed survey form via Google Form. The respondents were requested to answer the survey through the assistance of faculty members in the selected colleges/universities to facilitate the survey during their free time.

The works of Fabito et al (2021) were the main basis of the conduct of the study wherein the instrument used was adopted as a tool for data collection and analysis. The said instrument made some modifications which were also validated by the panel of evaluators together with external experts in the field of research. The online survey includes questions dealing with the a.) profile of students such as course, year level, location, and preferred learning modality b.) student devices used for an online class (with six criteria) c.) student internet connections (with five criteria), d.) student commitment to attend and participate class (with four criteria).

The researcher used descriptive statistics (frequencies, percentages, weighted mean) and Chi-square to analyze the data that was collected through a survey utilizing Google Forms and MS Excel. The application of descriptive statistics was used for the presentation of the demographic profile, student devices, internet connections, and class attendance capabilities. Moreover, the use of Chi-square is to determine the relationship of student demographic profile to different parameters included in the instruments. 


\section{RESULTS AND DISCUSSIONS}

In this section, the presented findings of the study will be discussed according to the stated objectives. First, the demographic profile of the computing students in online learning of selected public colleges and Universities in terms of courses, year level, learning modality, and location were determined. The study found that from 1300 respondents, 164 were BSCS students, 1087 were BSIT students, and 49 were from the BSIS program. This number was not surprising, given that the majority of the enrollees in the computing department were enrolled in the latter. For the year level, the 3rd year or had received the most responses yielding 440 or $33.85 \%$ of the total population. Following are the 2 nd year students who received total respondents of 424 representing $32.61 \%$ of all respondents, $1^{\text {st }}$ year students who received 347 or $26.70 \%$ responses, and, lastly, $4^{\text {th }}$ year students who received only 89 or $6.84 \%$ of all the respondents.

In terms of learning modality, the majority of the responses are blended learning or flexible learning with 391 or $30.07 \%$ of the followed by online learning with 320 responses or 24.61 , next is a combination of online and offline learning with 287 or $22.18 \%$ then the offline/modularity type with 246 or $18.92 \%$ and lastly, the respondents are not in favor to e-learning modality with 56 or $4.32 \%$. This results same as the study of Abisado, et al. (2020) as the majority of the students are ready for flexible learning delivery in terms of self-directedness towards learning.

The respondents from the different colleges and universities live in Town Proper with a total number of 802 or $61.69 \%$ of the respondents and it was followed by the lowland with 180 or $13.85 \%$ and upland with 105 or $8.08 \%$. The rest of the groups are from the mountain, island, remote area, beside the sea and no signal area at all which compress of $16.38 \%$ respectively. The digital divide among Filipino students is revealed by remote learning (Santos, 2020). This current state of remote learning has the most possibly exacerbated existing inequalities and can create a barrier in online learning (Rotas \& Cahapay, 2020).

\section{Devices Used for Online Learning}

In terms of per year level majority of the $3^{\text {rd }}$-year level have a laptop with a total number of 53 while most of the $2^{\text {nd }}$ year level and BSIT students used Smartphones in online learning but it also varies in all year levels and courses. The study found out that the majority of the respondents in the different SUC's engage in online learning through Smartphones or mobile devices with a total of 805 or $61.92 \%$ and some of the respondents have different devices used desktop, laptops, and smartphones with 317 or $24.38 \%$ while 127 respondents have the desktop or laptop, therefore, respondents rely on Smartphone if Desktop PC's and laptops are available as shown in Figure 1. It is obvious once the students are taking the computing and IT education, they are capable to have devices in online classes which are also shown in the study of Bringula, et al. (2021). 
Noticeably, the students only used smartphones or mobile devices as they are not able to buy desktop or laptops especially students residing in the province.

Table 1. Demographic Profile of the Respondents

\begin{tabular}{|c|c|c|}
\hline Categories & Frequency & Percentage \\
\hline \multicolumn{3}{|l|}{ State University and Colleges } \\
\hline SUC 1 & 158 & $12.15 \%$ \\
\hline SUC 2 & 105 & $8.07 \%$ \\
\hline $\mathrm{SUC}_{3}$ & 194 & $14.93 \%$ \\
\hline SUC 4 & 274 & $21.08 \%$ \\
\hline SUC 5 & 308 & $23.69 \%$ \\
\hline SUC 6 & 157 & $12.08 \%$ \\
\hline SUC 7 & 104 & $8.00 \%$ \\
\hline \multicolumn{3}{|l|}{ Degree Courses } \\
\hline BSCS & 164 & $12.61 \%$ \\
\hline BSIT & 1087 & $83.62 \%$ \\
\hline BSIS & 49 & $3.77 \%$ \\
\hline \multicolumn{3}{|l|}{ Year Level } \\
\hline $1^{\text {st }}$ Year & 347 & $26.70 \%$ \\
\hline $2^{\text {nd }}$ Year & 424 & $32.61 \%$ \\
\hline $3^{\text {rd }}$ year & 440 & $33.85 \%$ \\
\hline $4^{\text {th }}$ year & 89 & $6.84 \%$ \\
\hline \multicolumn{3}{|l|}{ Learning Modality } \\
\hline Online Learning & 320 & $24.61 \%$ \\
\hline Blended Learning & 391 & $30.07 \%$ \\
\hline E-learning & 56 & $4.32 \%$ \\
\hline Offline/Modular Type & 246 & $18.92 \%$ \\
\hline Combination of Online and Offline & 287 & $22.18 \%$ \\
\hline \multicolumn{3}{|l|}{ Location } \\
\hline Town Proper & 802 & $61.69 \%$ \\
\hline Upland & 105 & $8.08 \%$ \\
\hline Lowland & 180 & $13.85 \%$ \\
\hline Island & 3 & $0.23 \%$ \\
\hline Remote Area & 29 & $2.23 \%$ \\
\hline Beside the Sea & 43 & $3.31 \%$ \\
\hline No Internet/Signal Area & 67 & $5.15 \%$ \\
\hline Mountain & 71 & $5.46 \%$ \\
\hline
\end{tabular}




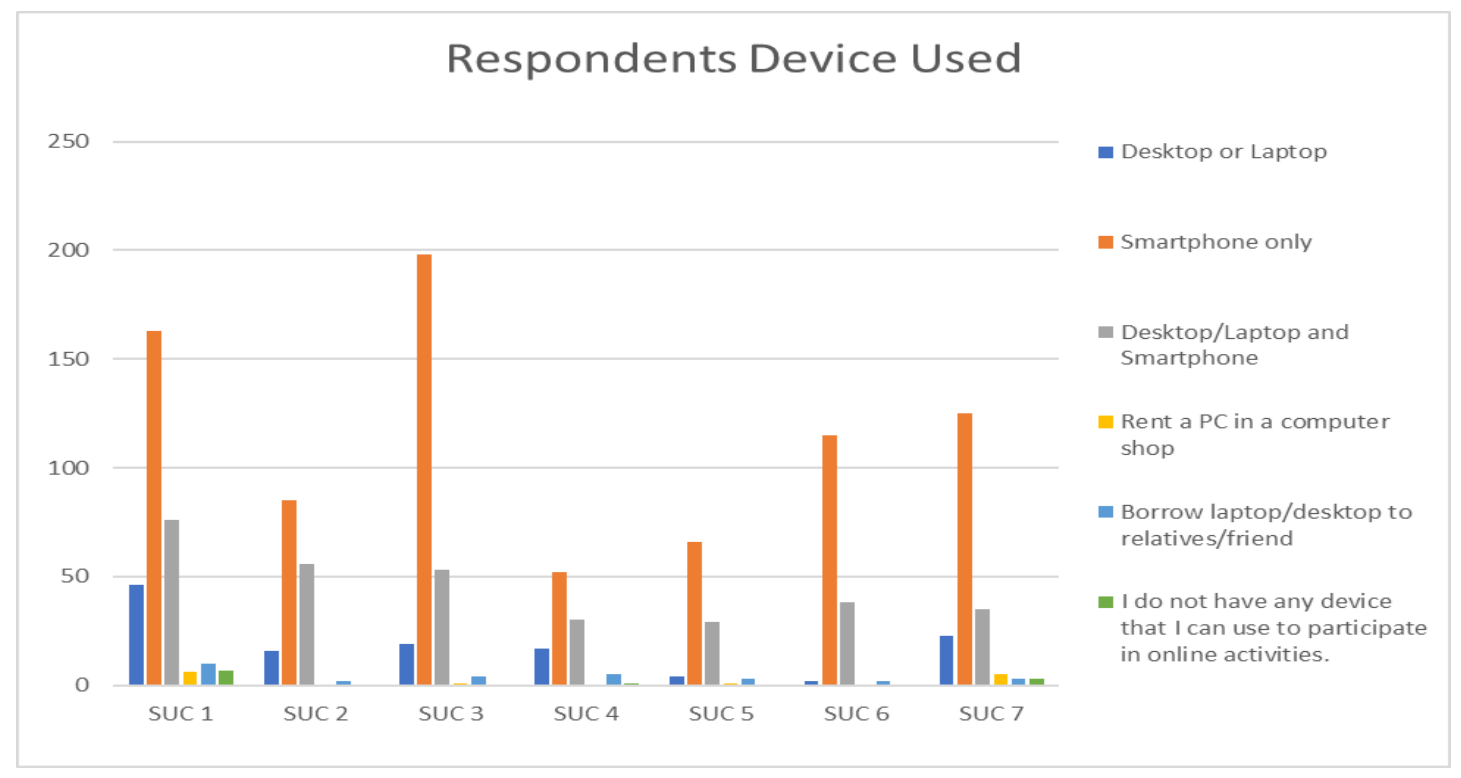

Figure 1. Respondent's Device Used

These findings are consistent with the study of Baticulon et al. (2021) who found that the majority of students use mobile devices or smartphones in their online learning, and also confirms the findings of Saavedra (2020), that access to remote learning devices such as computers/desktop/laptop has been a recurring challenge for students as schools shift to online learning and supported by Rotas and Cahapay (2020) that this problem may stem from financial issues as another difficulty disclosed by students.

\section{Internet Accessibility and Reliability}

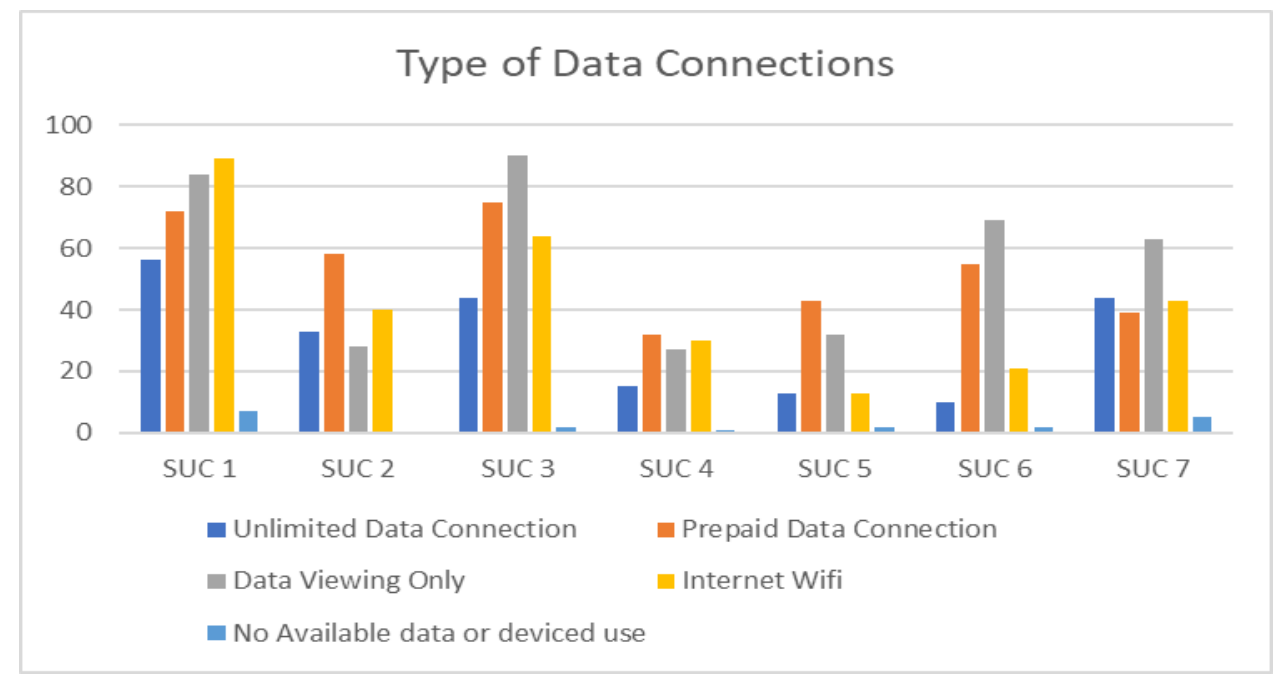

Figure 2. Respondent's Type of Data Connection

Findings show that prepaid data connection with 374 or $28.76 \%$ and data viewing connection with 393 or $30.23 \%$ of the entire population. While in terms of internet wifi 
with it has 300 or $23.08 \%$ of the respondents and 215 or $16.54 \%$ students has unlimited data connection who are enjoying continuous internet connection shown in figure 2. Regrettably, one of the challenges in prepaid data connections and data viewing is the data cup and limited access to online resources which have been crucial components of the students to participate and it is been experiencing the students and faculty during the classes which students suddenly disappeared because of the internet connection issues.

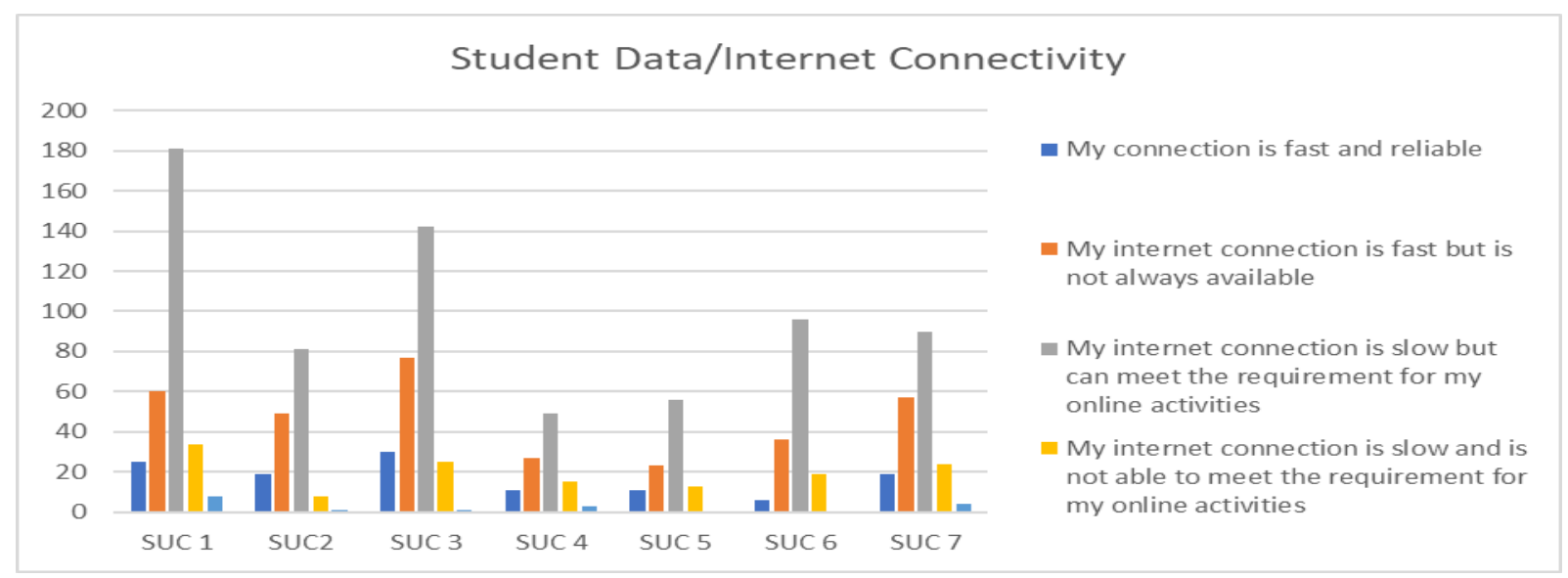

Figure 3. Respondent's Student Internet Connectivity

Previously, students need a constant internet connection to be fully engaged in online learning. This is especially true when all subjects enrolled require an online meeting. As observed, out of the 1300 students, Only $9.31 \%$ of them are experiencing a fast and reliable internet connection. Furthermore, according to the findings, $25.31 \%$ have access to a relatively fast internet connection, though it is not always available. It happens frequently because there are times when the internet connection is strong and then weakens on some occasions.

In terms of the poor connection, 695 people (or 53.46\%) say they are experiencing slow connection but adequate for their online activities. Finally, only 138 (or $10.61 \%$ ) have experienced a slow connection and are unable to meet their online requirements, while 17 (or $1.37 \%$ ) do not have to the internet at home. Overall, it can be interpreted that 1145 or $88.07 \%$ of the total respondents to the public state colleges and universities can slightly meet their online requirements in their classes as presented in figure 3.

These results of the type of data connection, and student internet connectivity are relatively consistent with previous studies (Abisado, et.al., 2020; Fabito, et.al, 2020; Rotas \& Cahapay, 2020) Students cited the raised of unstable internet connectivity as one of the main difficulties and challenging aspect of online learning, Morever, Baticulon, et.al, (2020) added that the availability of fast and reliable internet connection was a greater concern than device ownership or technical aptitude. As evidenced by the fact that the poor network is commonly a major issue for developing countries with telecommunication systems and ICT that have not been properly developed (Aboagye et al., 2020). 


\section{Relationship of Student's Profile to Mode of Teaching, Device Used in Participating Classes, and Student's Data Connection}

The year level of the respondents is Significant in terms of identifying the relationship to the mode of teaching because it has the $p$-value of .008 because once that the students are in the higher year level most likely they are adept in the mode of learning they already adopted the learning capabilities. However, the course and student's location are Not Significant because the level of significance is higher than 0.05 where it gained the p-value of 0.596 and 0.056 respectively as shown in Table 2.

Table 2. Significant Relationship between the profile of respondents and mode of teaching

\begin{tabular}{|l|l|l|l|l|l|}
\hline Variables & $\begin{array}{l}\text { Statistical } \\
\text { Tools }\end{array}$ & X2 Value & p-value & Decision & Interpretation \\
\hline Course & Chi-square & 6.460 & .596 & Accept Ho & $\begin{array}{l}\text { Not } \\
\text { Significant }\end{array}$ \\
\hline Year Level & Chi-square & 26.869 & .008 & Reject Ho & Significant \\
\hline $\begin{array}{l}\text { Student } \\
\text { Location }\end{array}$ & Chi-square & 40.764 & .056 & Accept Ho & $\begin{array}{l}\text { Not } \\
\text { Significant }\end{array}$ \\
\hline
\end{tabular}

Table 3 shows that the year level of respondents has the p-value lesser than the .05 level of significance thus the null hypothesis is rejected since it is Highly Significant based on a p-value of .000 in terms of device use in participating classes. Moreover, the course of the respondents is Significant since the p-value is equivalent to .011 and student location with the p-value of .002 which is also Significant. This is related to the finding of Sanwar, et.al, (2020) who found that students situated in deep, and remote rural areas find it difficult to stay connected to online learning due to power outages.

Table 3. Significant Relationship between the profile of respondents and device use in participating class

\begin{tabular}{|l|l|l|l|l|l|}
\hline Variables & $\begin{array}{l}\text { Statistical } \\
\text { Tools }\end{array}$ & X2 Value & p-value & Decision & Interpretation \\
\hline Course & Chi-square & 22.847 & .011 & Reject Ho & Significant \\
\hline Year Level & Chi-square & 52.174 & .000 & Reject Ho & $\begin{array}{l}\text { Highly } \\
\text { Significant }\end{array}$ \\
\hline $\begin{array}{l}\text { Student } \\
\text { Location }\end{array}$ & Chi-square & 64.556 & .002 & Reject Ho & Significant \\
\hline
\end{tabular}

In table 4 shows the student location is Highly Significant to the student data connection since the $p$-value is .000 . While assessing the relationship of the year level to the student data connection gained a p-value of .001 which is Significant. However, in terms of relationship to the course and student data connection, it is Not Significant with 
the p-value of . 331 which is higher than the level of significance which is .05 . The course is not significant because it is obvious that they belong to computing and IT education fields therefore the year level and the student location have a significant relationship to student data connection because respondents are expected to be inclined and must have a data connection and higher capabilities in online learning.

Table 4. Significant Relationship between the profile of respondents and student data connection

\begin{tabular}{|l|l|l|l|l|l|}
\hline Variables & $\begin{array}{l}\text { Statistical } \\
\text { Tools }\end{array}$ & X2 Value & p-value & Decision & Interpretation \\
\hline Course & Chi-square & 9.136 & .331 & Accept Ho & $\begin{array}{l}\text { Not } \\
\text { Significant }\end{array}$ \\
\hline Year Level & Chi-square & 32.044 & .001 & Reject Ho & Significant \\
\hline $\begin{array}{l}\text { Student } \\
\text { Location }\end{array}$ & Chi-square & 77.434 & .000 & Reject Ho & $\begin{array}{l}\text { Highly } \\
\text { Significant }\end{array}$ \\
\hline
\end{tabular}

\section{Capabilities to Attend Class and Submit Requirements}

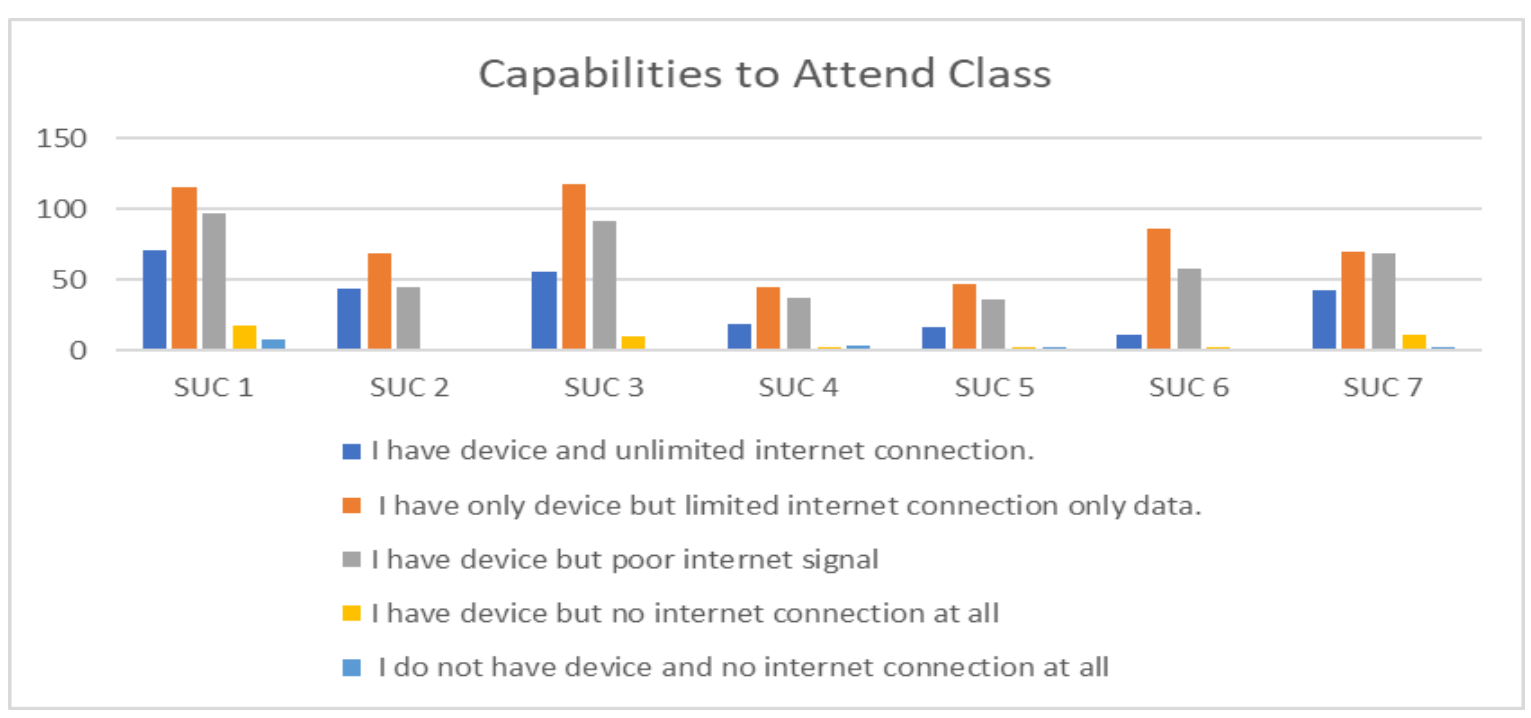

Figure 4. Respondent's Capabilities to Attend Class

The ITE's students in the public colleges and universities are capable to attend class, most of the respondents answered that $42.31 \%$ have a device but limited internet connection only data and 33.31 of the respondents have devices but poor internet signal as presented in Figure 4. The results about the internet problem connections in attending class in which based on the new article Philippines is one of the countries who have slowest internet connection in Asia and most of the students are not able to have the postpaid and continuous connection (unlimited connection) in their house what's why students tend to use prepaid data for their online needs because it is the convenient and easy way to attend classes using their mobile devices. Most students do not have access 
to high speed and reliable internet service is noticed by Ahmad (2020) and Adnan \& Anwar (2020) have discovered, that they struggle with online learning.

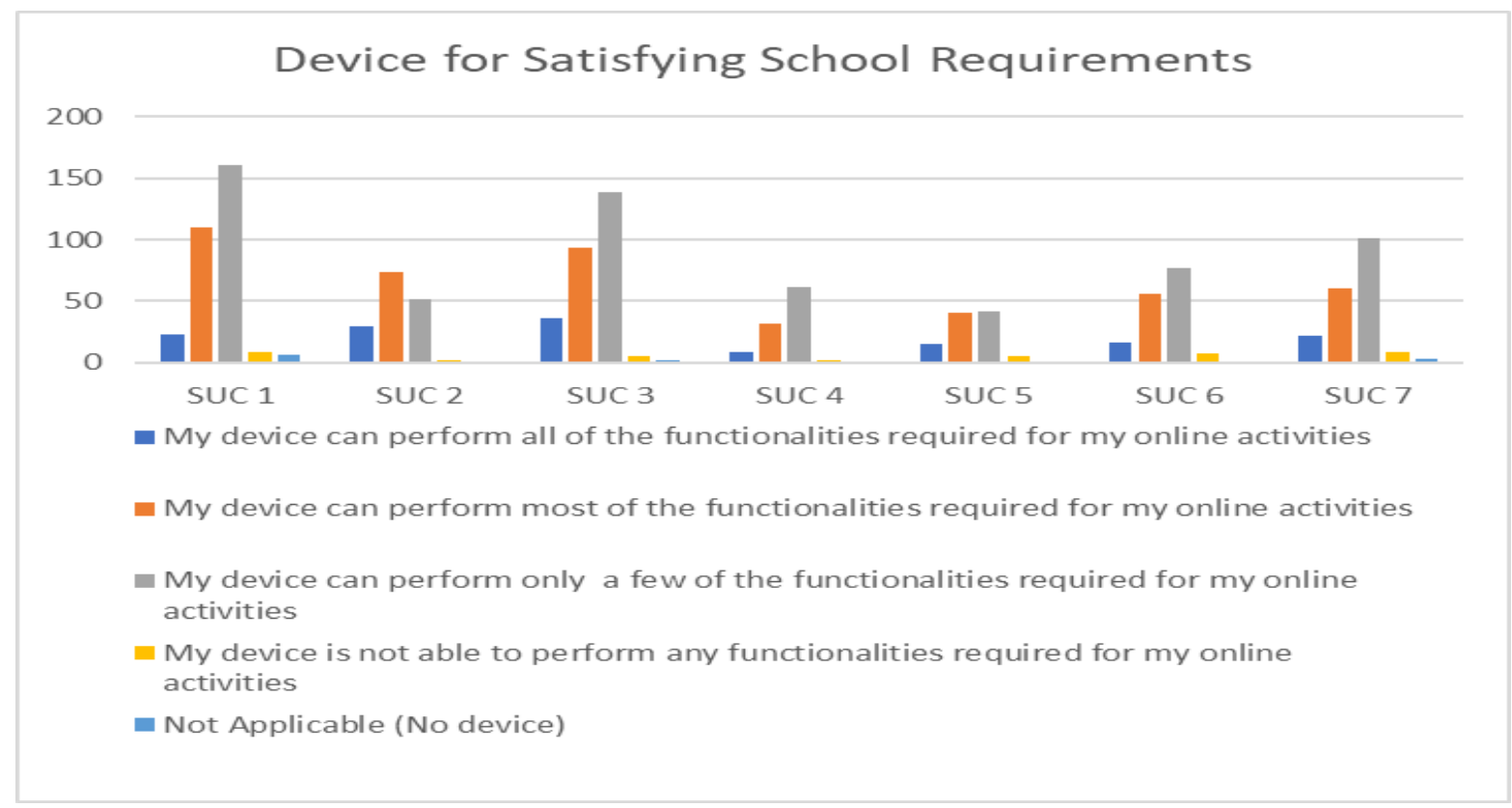

Figure 5. Respondent's Device for Satisfying School Requirements

The students in the public colleges and universities are capable to attend classes using their Smartphones as their device to participate and attend class however when it comes to meeting school requirements $48.69 \%$ of the population says their device can perform only a few of the functionalities required for online activities, $2.84 \%$ of the populations says their device can't perform any functionalities required for online activities, and lastly, $1.15 \%$ of the population says it's not applicable because no device was used to submit school requirements, as shown in figure 5. One in every five students lack access to a computer and had to rely on prepaid mobile data to stay connected (Baticulon, et.al., 2020).

Table 5. Significant Relationship between the capability to attend online classes and commitment to attend/participating classes and submitting requirements

\begin{tabular}{|l|l|l|l|l|l|}
\hline Variables & $\begin{array}{l}\text { Statistical } \\
\text { Tools }\end{array}$ & X2 Value & p-value & Decision & Interpretation \\
\hline Capability & Chi-square & 311.537 & .000 & Reject Ho & $\begin{array}{l}\text { Highly } \\
\text { Significant }\end{array}$ \\
\hline Commitment & Chi-square & 311.537 & .000 & Reject Ho & $\begin{array}{l}\text { Highly } \\
\text { Significant }\end{array}$ \\
\hline
\end{tabular}


Table 5 presents that the capability of the students to attend online classes in terms of submitting requirements is highly significant ( $p$-value $=.000)$. Likewise, the commitment of the students to attend/participate in classes in terms of submitting requirements is highly significant $(p$-value $=.000)$.

\section{CONCLUSIONS AND RECOMMENDATIONS}

Due to the effect of Covid 19-pandemic, educational institutions, particularly in the Philippines, face insurmountable challenges in their planning, implementation, and assessment system. The study identifies different interrelated challenges such as the majority of the student only using smartphones in online learning and poor internet connection due to financial difficulties as they tried to adapt to online learning because they are committed to participating and submitting requirements. The study gives insights into the current condition experienced by the students in the school administrations and officials, and faculty as well to strengthen the appropriate online teaching mode and other practices applicable to the students. It can also be used to emphasize the importance of being more responsive to the learning needs of IT students, particularly outside of the traditional classrooms.

To help the need of devices such as laptop or desktop for students it is better to develop a mobile application which assists the students especially in the different programming and professional subjects of the computing student which also facilitate a push notification and alert when new activities and deadlines submission. A mobile application that manages and monitors the classes which capable students to collaborate and more engage like gamification approach even offline. Hence the result, faculty members must receive training to design a pedagogy that is appropriate for online learning. To address the pedagogical concern of students in online learning, management should adopt a policy that would institute continuous training and monitoring for faculty members.

It is suggested that these difficulties should be viewed as inputs for the current educational process's further development. Officials from schools or universities should advocate for better improvement of technology and resources, particularly in rural areas. furthermore, educational institutions must create appropriate and effective content, set up an effective, and efficient delivery system, and provide digital literacy training to current faculty to improve learning outcomes. Lastly, it is encouraged to establish a strong Information Communication Technology Office that focuses on the development of a different website and mobile application that assist the need of the students and faculty. Research on the lack of on-campus socialization and work from home of students and faculty in online learning is also important in crafting policies and learning framework that deals with the improvement of responsive curriculum to the computing field and design appropriate content for online and offline learnings. 


\section{IMPLICATIONS}

The findings of this study provide direct implications for universities' and colleges' administrative officials to formulate a policy to help and assist students in online learning especially those who are in remote areas and cannot able to avail load for data or internet connection to participate and submit requirements in their course. Moreover, it is better to have consistent monitoring of the students who are not able to attend classes, feedback of students and teachers in their classes, and coping mechanisms in online learning.

The researcher suggests that the implementation of continuous webinar/seminars and ICT training for the students and teachers regarding dealing effective online environment classes, open-source and friendly ICT tools for learning, mental awareness, teaching strategies especially in ITE courses and coping mechanisms are important to slowly adopt the online learning setup. Creating complete courseware for both online and offline mode for students that provide complete resources and materials capable to use via mobile and web application that supports the need of students and teachers in an online learning environment.

\section{REFERENCES}

Abisado, M. B., Unico, M. G., Umoso, D. G., Manuel, F. E., \& Barroso, S. S. (2020). A flexible learning framework implementing asynchronous course delivery for Philippine local colleges and universities. International Journal, 9(1.3).

Aboagye, E., Yawson, J. A., \& Appiah, K. N. (2021). COVID-19 and E-learning: The challenges of students in tertiary institutions. Social Education Research, 2(1), 1-8.

Adnan, M., \& Anwar, K. (2020). Online learning amid the COVID-19 pandemic: Students' perspectives. Journal of Pedagogical Sociology and Psychology, 2(1), 45-51.

Ahmad, I. (2020, April 5). Fata and the internet. Retrieved from The News: https://www.thenews.com.pk/print/639470-fata-and-the-internet

Bao, W. (2020). COVID-19 and online teaching in higher education: A case study of Peking University. Human Behavior and Emerging Technologies, 2(2), 113-115.

Bringula, R., Batalla, M. Y., \& Borebor, M. T. (2021, October). Modeling computing students' perceived academic performance in an online learning environment. In Proceedings of the 22nd Annual Conference on Information Technology Education (pp. 99-104).doi: 10.1145/3450329.3476856

Cao, W., Fang, Z., Hou, G., Han, M., Xu, X., Dong, J., \& Zheng, J. (2020). The psychological impact of the COVID-19 epidemic on college students in China. Psychiatry Research, 287, 112934.

Duddu, P. (2020). Coronavirus in Philippines: The COVID-19 risk, impact and measures. Retrieved by: https://www.pharmaceutical-technology.com/features/coronavirusaffected-countries-philippines-measures-impact-tourism-economy/ 
Gondauri, D., Mikautadze, E., \& Batiashvili, M. (2020). Research on COVID-19 virus spreading statistics based on the examples of the cases from different countries. Electron J Gen Med, 17(4), em209.

Lausa, S., Bringula, R., Catacutan-Bangit, A. E., \& Santiago, C. (2021, April). InformationSeeking Behavior of Computing Students while Programming: Educational Learning Materials Usage, Satisfaction of Use, and Inconveniences. In 2021 IEEE Global Engineering Education Conference (EDUCON) (pp. 761-765). IEEE.

Li, C., \& Lalani, F. (2020). The COVID-19 pandemic has changed education forever. This is how. Retrieved 25th November 2020 from https://www.weforum.org/agenda/2020/04/coronavirus-education-globalcovid19online-digital-learning/

Madhok, R., Frank, E., \& Heller, R. (2018). Building public health capacity through online global learning. Open Praxis, 10(1), 91-97.

Mailizar, A., Abdulsalam, M., \& Suci, B. (2020). Secondary school mathematics teachers' views on e-learning implementation barriers during the COVID-19 pandemic: The case of Indonesia. Eurasia Journal of Mathematics, Science \& Technology Education, 16(7), 1-9.

Makina, A. (2020). Developing a framework for managing the quality use of podcasts in open distance and e-learning environments. Open Praxis, 12(1), 67-81.

Meng, L., Hua, F., \& Bian, Z. (2020). Coronavirus disease 2019 (COVID-19): emerging and future challenges for dental and oral medicine. Journal of dental research, 99(5), 481-487.

Power, E., Hughes, S., Cotter, D., \& Cannon, M. (2020). Youth mental health in the time of COVID-19. Irish Journal of Psychological Medicine, 32, 93-105.

Rapanta, C., Botturi, L., Goodyear, P., Guàrdia, L., \& Koole, M. (2020). Online university teaching during and after the Covid-19 crisis: Refocusing teacher presence and learning activity. Postdigital Science and Education, 2(3), 923-945.

Rotas, E. E., \& Cahapay, M. B. (2020). Difficulties in Remote Learning: Voices of Philippine University Students in the Wake of COVID-19 Crisis. Asian Journal of Distance Education, 15(2), 147-158.

Saavedra, J. (2020). Educational challenges and opportunities of the Coronavirus (COVID19) pandemic.World Bank Blogs. Retrieved from https://blogs.worldbank.org/education/educational-challenges-and-opportunitiescovid-19-pandemic

Santos, A. P. (2020, October 6). In the Philippines, distance learning reveals the digital divide. Retrieved from https://eu.boell.org/en/2020/10/06/philippines-distancelearning-reveals-digital-divide

Simbulan, N. (2020). COVID-19 and its impact on higher education in the Philippines. Higher education in Southeast Asia and Beyond, 8, 15-18.

Sintema, E. J. (2020). Effect of COVID-19 on the performance of grade 12 students: Implications for STEM education. Eurasia Journal of Mathematics, Science and Technology Education, 16(7), em1851.

Toquero, C. M. (2020). Challenges and opportunities for higher education amid the COVID-19 Pandemic: The Philippines Context. Pedagogical Research, 5(4), emoo63 
UNESCO (2020). Global Monitoring of School Closures caused by COVID-19. Retrieved from https://en.unesco.org/covid19/educationresponse

Walsh, F. (2020). Loss and resilience in the time of COVID-19: Meaning-making, hope, and transcendence. Family Process, 59(3), 898-911. https://doi.org/10.1111/famp.12588

Yusuf, B. N., \& Jihan, A. (2020). Are we prepared enough? A case study of challenges in online learning in a private higher learning institution during the Covid-19 outbreaks. Advances in Social Sciences Research Journal, 7(5), 205-212.

Yan, Z. (2020). Unprecedented pandemic, unprecedented shift, and unprecedented opportunity. Human Behavior and Emerging Technologies. Advanced online publication. doi: 10.1002/hbe2.192 